\title{
The Specificity of Units with Specialized Meaning: Polysemy as Explanatory Factor*
}

\author{
(A Especificidade das Unidades com Sentido Especializado: \\ a Polissemia como Fator Explanatório)
}

\author{
Andreína Adelstein \\ (Universidad Nacional de General Sarmiento - Argentina) \\ María Teresa CABRÉ \\ (Institut Universitari de Lingüística Aplicada, \\ Universitat Pompeu Fabra - Barcelona-Spain)
}

\begin{abstract}
In linguistics and terminology, few are the works that describe, in an integrated manner, terminological units and words. Neither are there models explicitly including, in their lexical representation, specialized meanings. We start from the bypothesis which states that the lexical unit $(L U)$ is not per se either word or term, but a lexical form associated to all information relative to the different modules of the grammar in which it participates (Cabré 1999d, 2000). According to the communicational situation in which it is used, it either activates or not a specialized value. These values maintain a polysemic relationship with each other. The goals of this paper are to establish some elements that allow for an empirical foundation for the stated hypothesis on the $L U$, and to describe the kinds of features that compose semantic information and the configurations activated in specialized meanings.
\end{abstract}

KEY Words: Lexical unit; Terminological unit; Polysemy; Lexical representation.

Resumo: Nas áreas de lingüística e terminologia, poucos são os trabalhos que descrevem, de uma maneira integrada, unidades terminológicas e palavras. Também não há modelos que incluam explicitamente, na representação lexical, os sentidos especializados. Partimos da hipótese de que a unidade lexical (UL) não é intrinsicamente nem palavra nem termo, mas uma forma lexical associada a toda informação relativa aos diferentes

* Translated from Spanish by Gabriela Adelstein

D.E.L.T.A., 18:EsPECIAL, 2002 (1-25) 
módulos da gramática na qual ela ocorre (Cabré, 1999d, 2000). Em função da situação comunicacional na qual ela é usada, a unidade lexical ativa ou não um valor especializado. Esses valores mantêm uma relação polissêmica entre si. Os objetivos deste artigo são definir alguns elementos que forneçam um fundamento empírico para a hipótese citada e descrever os tipos de traços que compõem a informação semântica e as configurações ativadas pelos sentidos especializados.

Palavras-chave: Unidade lexical; Unidade terminológica; Polissemia; Representação lexical.

\section{Introduction}

Terminology, devoted to the units of specialized meaning, i.e. terminological units (TU), has been historically defined as an autonomous discipline, different from linguistics and/or lexicology (Wüster, 1979; Felber, 1984; Picht, 1996).

Those who consider that linguistics cannot either describe or explain the units of specialized knowledge argue that linguistics must address natural language, whereas terminology theory must deal with specialized concepts, sometimes expressed through linguistic units and sometimes materialized through non-linguistic units. They also state that terminology is an autonomous discipline that studies knowledge, taking elements from other disciplines but constituting a specific field of its own. They add that the basic attitude of terminology vis à vis languages is determined by prescription and by voluntary consensus, in order to attain a specialized communication with no interpretative fissures. Consequently, they make a distinction between term or $T U$ (object of terminology) and word (object of linguistics).

Currently, nevertheless, the interest of lexicologists, lexicographers, linguists and translators regarding units and specialized texts (Rey, 1998/ 1999; Cabré, 1999, 2000a, 2000b; Lara, 1998/1999, 1999; Sager, 1998/ $1999,2000)$ evidences that, from a linguistic perspective of the terminological object, such a stand is inadequate. The specificity of the units of specialized meaning would not require a theory of terminology, but rather a theory about terms (Lara, 1998/1999; Cabré, 2000b). 
The subject of this paper, is, therefore, the specificity of TUs, explained from a polysemic perspective of the lexical units of natural language.

The goals are, on one hand, to present and empirically prove a hypothesis about the organization of the semantic information of the lexical unit that may account for specialized meanings and, on the other hand, to demonstrate the operativity of a polysemy model to distinguish the specialized senses from the non-specialized ones.

We will note the characterization generally attributed to terms by opposition to words $(\S 1)$. Then we will present the hypotheses and theoretical assumptions we started from $(\S 2)$, the analysis of the Spanish LU cabeza [head] $(\S 3 \text { and } \S 4)^{1}$ and the characteristics of the specialized senses $(\S 5)$. Finally, we will state brief conclusions about the consequent model of polysemy $(\S 6)$.

\section{Term and word}

The characterization of the terminological unit is a problem of linguistic nature, as the terminology unit (either the terminological work unit, or the unit that is the object of theoretical description and explanation) overlaps with the lexicology unit. This is why, traditionally, attempts have been made to separate and distinguish "term" from "word".

In previous papers (Adelstein \& Cabré, 2000; Adelstein, 2001) we have noted that, in linguistics literature, few are the works that describe, in an integrated manner, TUs and words. We have also verified that neither are there models explicitly including, in their lexical representation, specialized meanings.

In fact, until recent years, insofar as the term's properties were enunciated by opposition to those of the word, the "reasons" alleged to exclude terms from the study field of lexicology and to consider them the study object of a "new discipline" were the same.

The distinctive features of the TU noted both by lexicology and by terminology are: (i) monosemy and mononimy; (ii) nominal character; (iii)

1 This paper is based on Adelstein (2001), and presents part of its results. 
non-interdependence between meaning and form; and (iv) appurtenance to a single specialty thematic field.

Thus, in general, neither lexicology nor semantics have accounted for specialized units. We may nevertheless mention different attitudes regarding the issue:

a) specialized units have been ignored in the description and explanation of lexical meanings (among others, Lyons, 1981; Mounin, 1972; Leech, 1981);

b) they have been explicitly discarded as study object (Coseriu, 1977);

c) they have been considered as object of a specialized lexicology or in relation to neological processes (e.g., Guilbert, 1975).

On the other hand, terminology distinguishes the notions of term and word, for epistemological reasons:

a) an epistemological need of an unit of analysis of its own;

b) postulates oriented towards terminological work and/or towards linguistic planning ${ }^{2}$

c) a theoretical perspective more directed towards knowledge representation than towards a description of the linguistic nature of knowledge units.

In terminology, there are more linguistic answers to the issue of which is the semiotic statute of the $\mathrm{TU}^{3}$, although few authors hypothesize that it is, in fact, one unit. ${ }^{4}$

\footnotetext{
2 Terminology was originally devoted to delimitate guidelines for terminological work, and to set the requirements for an ideal terminological unit for efficient and univocal funciotioning of scientific and technical communication. Theoretical analysis was directed at terminological practice itself. Thus, on ocasion, proposals of methodological postulates were considered theoretical principles. Therefore, a confusion obtained between the work unit and the real sepecialized unit (which es a natural language unit); so, the real terminological unit was caracterized as from the ideal unit ideal. 3 Bejoint \& Thoiron (2000b); Bouveret (1998); Condamines (1994, 1995); Condamines \& rebeyrolles (1997); Lara (1998/1999, 1999); Meyer, Mackintosh (2000); Meyer, Mackintosh, Varantola (1997); Sager (1998/1999, 2000); Slozdian (1995, 2000); Temermann (1997, 1998, 1998/1999).

${ }^{4}$ Neverthless, papers have been published that analyze specialized and non-specialized meaning of a single lexical form, from a polysemic perspective, among which Candel (1984), Meyer et al. (1997), Condamines; Rebeyrolles (1997) and Meyer et al (2000). Among those following a homonimic perspective, Ahmanova (1974, apud Rondeau, 1984).
} 
From the elements provided by these authors we conclude that:

- the term is conceived as a meaning acquired by a lexical unit in a context of specialized communication;

- the term must be studied within its context;

- the specificity of the term resides in one of the following features:

(i) the communicational situation where it is employed;

(ii) the specialization of its semantic features;

(iii) the knowledge it represents;

(iv) the type of signification.

\section{LU hypothesis and theoretical assumptions}

For us, term and word are not different units: we start from the CTT (Communicative Theory of Terminology) (Cabré 1999, 2000; Cabré \& Adelstein 2001; Adelstein \& Cabré, 2000a), which states that the lexical unit (LU) is not per se either word or term, but rather a lexical form associated to all information relative to the different modules of the grammar of which it participates. According to the communicational situation in which it is used, it either activates or not a specialized value. These values maintain a polysemic relationship with each other.

The semantic information of the $\mathrm{LU}$ is organized in features and feature modules that are activated in different ways according to each situation, and thus give way to one of the possible senses of the LU. ${ }^{5}$

This hypothesis calls for the adoption of a series of theoretical assumptions regarding:

1) the signification process and the determination of sense;

2) the multiplicity of senses of a single form and the concept of polysemy;

3) the notions of meaning and sense.

\footnotetext{
5 A similar approach may be found in Rastier (1987)
} 
1) As regards the signification process, the concept of activation manifests the cognitive approach of this theory. That is, it presupposes that the semantic information pertaining to each sense is selected by a cognitive process. Therefore, sense and activation designate the same linguistic phenomenon. Activation refers to the cognitive process through which the semantic elements corresponding to a determinate use of the LU are actualized. Sense designates the "product" of such process: the activated semantic information.

From this perspective, and following Récanati (1997), the two main currents regarding the determination of sense are:

a) "fixism": lexical meanings are fixed in the language, and therefore the determination of sense would consist in a selection;

b) "sense generation": sense is not fixed but constructed; thus, the determination of sense depends from the verbal or situational context. In this tendency, Récanati includes, on the one hand, works that state that sense generation follows the interaction of the elements of the phrase in which the polysemic word is employed (the "segregationism" of Pustejovsky and Victorri). Then, on the other hand, there are those who think that the sense does not "exist" in the language but that it is created by usage, and he calls this tendency "contextualism".

Our own stand would be similar to "segregationism".

2) As regards the multiplicity of senses of a single form, the explanation that lexical semantic information is organized in "activable" features would allow, first, to account for the distinction between specialized and non-specialized meanings, as well as for every semantic variation ${ }^{6}$ relative to a lexical form.

Secondly, it would make room for the explanation of the types of semantic variation traditionally attributed to specialized meanings: according to thematic fields (horizontal variation), according to specialization

${ }^{6}$ By variation or semantic diversity we wish to denote, in a general way, the different types of polysemy and conceptual or meaning variants of a single linguistic form. Other authors call this phenomenon sense-spectra (Cruse, 1986: 71-74), semantic space (Victorri, 1996), semasiologic variation (Geeraerts, Grondelaers, Bakema, 1994), or lexical variation (Temmerman, 1995). 
levels (vertical variation), according to modulation (author, school, perspective), and according to point of view (way to broach the subject). It would also allow for the integration, in lexical description, of diverse polysemyzation processes in specialized domains, that is, the phenomena studied by the Meyer team under interdomain polysemy ${ }^{7}$, intradomain polysem $^{8}$, terminologization and determinologization ${ }^{9}$, as well as the phenomena of metaphorization, demetaphorization and revitalization analyzed by Temmerman $(1995,1998)$, and the six types of polysemy noted by Bouveret (1998).

In any case, insofar as our own perspective is linguistic, and as we do not consider the difference between meaning and concept to be useful, we believe that all typologies may be reduced to the following general types:

- regular polysemy: variation in which there is no change in denotation, occurring regularly in the LUs of a same semantic class;

- asystematic polysemy: variation in which there is change in denotation, often occurring irregularly;

- conceptualization: variation in the way of conceiving the referent, which does not imply a change in denotation.

Regarding the explanations received by the polysemy phenomenon, we may generalize and state that they consist in maintaining that they are ${ }^{10}$

a) fixed meanings, listed in the lexical entry as definitions of a lexicographical entry (Martin, Katz, apud Victorri \& Fuchs, 1996).

b) a meaning core or a basic sense, shared by all meanings (Geeraerts, 1990, 1995; Lakoff, 1986, 1987, 1997; Kleiber, 1999; Fillmore \& Atkins (2000); Fodor y Cadiot, apud Victorri \& Fuchs, 1996; Moura, 2001).

\footnotetext{
7 That is, the senses a term acquires in other domains. Contrary to horizontal variation, it implies that the meaning it has in one domain was generated from the one in the other domain. Horizontal variation does not necessarily imply this origin relationship.

${ }^{8}$ Meyer; Mackintosh (2000) use the expression intradomain polisemy when a determinologized word "goes back" or "reinfiltrates" the original specialty domain.

9 These processes whould establish polysemy relationships between specialized and nonspecialized uses.

${ }^{10}$ For a state of the art of polysemy, see Victorri \& Fuchs (1996), Kleiber (1999) and Ravin \& Leacock (2000).
} 
c) a first meaning from which all the others derive (Picoche, apud Victorri \& Fuchs, 1996 and the relational models).

d) a series of elements activated or focused according to each sense, many of which (not always the same ones) are shared by groups of senses (Apresjan, 1974; Rastier, 1987; Pustejovsky, 1995).

For us, polysemy and/or semantic variation must be explained according to $(\mathrm{d})$.

3) As to the notions of meaning and sense, in general it is considered that the variants of asystematic polysemy are meanings; and that variants corresponding to other types of polysemy and of conceptual variation are senses or uses of the same meaning. We think meaning and variant should not be distinguished a priori. We will talk about sense, defined as any activated semantic configuration of a LU, motivated by certain parameters, e.g. syntactic, textual, pragmatic, referential, situational, etc.

In synthesis, given the starting LU hypothesis we are trying to false, our assumptions are:

1) there is no specialized lexicon, i.e. discriminated from the general lexicon; it is the same lexical competence: specialized and nonspecialized are different activations of the same lexical semantic information. Sense is dynamically determined;

2) the activation process of semantic elements allows for the explanation of all kinds of semantic variation or polysemy;

3) no a priori discrimination must be made between denotative senses and connotative or argumentative senses, between meaning, sense and use. They may all be explained through the same activation mechanism.

\section{Observation: corpus, methodology and description of data}

This section attempts to present partial results of the exploratory observation developed in Adelstein (2001) in order to establish some elements that may constitute an empirical foundation for the lexical unit hypothesis, particularly as regards semantic information. 
Said research selected four simple non-constructed nouns: madre [mother], cabeza [head], familia [family] and vaso [glass, vessel]. We will here use cabeza as example.

To extract semantic information we considered entries in 4 Spanish language dictionaries, 3 science dictionaries, 3 botany dictionaries, 3 chemistry dictionaries, 4 medicine dictionaries and 4 biology dictionaries. ${ }^{11}$

Methodology consisted in fragmenting ad maximum the semantic information of the $\mathrm{LU}$, in order to extract its constitutive elements and thus observe both activation possibilities and the relations between specialized and non-specialized senses. Procedures were basically two:

(i) to group and organize information from the various dictionaries, so as to formulate an exhaustive proposal of the senses of the LU;

(ii) to observe represented information, and propose a list of the constitutive semantic elements as per the contrasting of delimited senses.

Following are the results of data description for the example cabeza.

The contrasting of lexicographical information allowed us to identify 35 senses for cabeza. For their integral organization, generalizing basic notions were considered: "extreme part", "round part" and "extreme and round part".

In the grouping "extreme and round part" we considered ten senses (c1-c10) for the part of the animal body, as per human or non-human referent, specialization level and point of view (see Annex II, table 1). As regards the points of view, both for animal and for human referents, we noted: container and content, the container in its cranial and facial parts, and the cranial part.

We also distinguished a subgroup "extreme and round part of something" where we delimited nine senses (c11-c18) as per type of reference, thematic field and specialization level. Senses of non-specific or very general referents were also noted (e.g. elongated objects), as registered in the general dictionaries (see Annex II, table 2).

${ }^{11}$ For references and dictionaries codification, see Annex I. 
Under the grouping "extreme part", the perspective of location was considered: the ten senses (c19-c28) were delimited as per the location of the part in the whole (superior, proximal, anterior o non-specified), type of reference, thematic field and specialization level (see Annex II, table 3).

Finally, under "round part" we distinguished seven senses (c31-c35) as per type of reference, specialization level and thematic field (see Annex II, table 4).

\section{Observation: analysis and theoretical proposals}

In the analysis of data we tried to answer the following questions:

a) which elements conform the semantic information of the LU;

b) how such elements are activated;

c) which is the specificity of specialized activations.

a) Elements:

As a first generalization of observed data, the following hypothesis was formulated: the LU would seem to present a basic semantic structure, of the predicative type, constituted by at least three components (two arguments and a predicate), which is specified in various ways (as regards both predicate and arguments), according to each of its senses. In the case of cabeza, [[ [ $\mathrm{x}_{\mathrm{x}}$ BE PART OF $\left.]_{\mathrm{z}} \mathrm{y}_{\mathrm{z}} \mathrm{CONTAIN}_{\mathrm{w}}\right]$.

Nevertheless, contrasting among senses allowed us to verify that they do not constitute different specifications of said structure. In spite of it, the notion of basic semantic structure permitted us to maintain that the LU's two essential types of semantic elements or features are either predicates (relations, processes, states, attributes, etc.), or semantic arguments (participants in such predicates). Therefore, the LU has no basic semantic structure inherited or specified according to each sense, but rather its senses are activations of at least one predicate, to which at least one argument is linked.

We therefore reformulated the hypothesis thus: the LU's semantic information consists in a relevant quantity of predicates and of semantic 
arguments, whose possible combinations conform each one of the unit's senses. ${ }^{12}$

Thus, from this perspective, the $\mathrm{LU}$ is not a form linked to various listed (and somehow related) meanings, but to what could be called a "macro" meaning. In other terms, the meanings of a LU are not "senses" that "repeat" information also contained in other senses (or in some of them), but possible updatings of combinations of the features (predicates and semantic arguments) of said "macro" meaning. A metaphor for this semantic organization is that of a network allowing for diverse courses or paths and different destinations.

By predicate we understand one of the kinds of elements that make up the semantic information of a LU; they are processes, states and attributions, and are set in small capitals. Every predicate has one or more argumental loci, set as subindexes. For instance, some of the predicates of madre are ${ }_{\mathrm{x}}$ PRODUCE; ; $_{\mathrm{x}}$ CRYSTALLIZE; $\mathrm{x}$ EVAPORATE. In familia, some of the predicates activated in several senses are ${ }_{x}$ DESCEND $_{y}$; ${ }_{x}$ BE UNIT or $x, y$ SHARE $_{z}$. As regards cabeza, we may mention CONTAIN $_{\mathrm{y}}$; $\mathrm{BE}$ PART OF ${ }_{\mathrm{y}}$ and $\mathrm{x}$ BE HEMISPHERICAL.

The other kind of semantic elements corresponds to the information that "fills" the argumental loci of predicates. We will therefore talk about argumental locus to refer to the elements selected by a predicate (i.e. logical arguments) and about semantic argument to refer to the semantic information that fills an argumental locus. Thus, a semantic argument is not associated to any particular predicate. We will represent the semantic arguments in brackets and argumental loci, as mentioned above, in subindexes.

Thus, the semantic elements of cabeza derived by sense contrasting are: ${ }^{13}$ :

\footnotetext{
12 The underlying idea of this hypothesis is that a sense or meaning is a series of predications (set of activated predicates and arguments). Our use of predicate, argument, atribution, process or state must not be interpreted according to a particular model, but rather in their more general linguistic sense. Nevertheles, our hypothesis is related to certain elements proposed by Leech (1981).

13 In Adelstein (2001: 174-180) we offer a typology of predicates according to the quantity of argumental loci, type of predication and internal structure.
} 


\section{- Predicates}

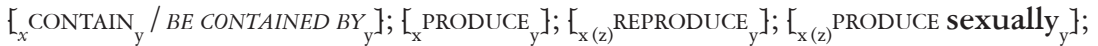
$\left[_{\mathrm{x}}\right.$ PRODUCE asexually $\left.\mathrm{y}_{\mathrm{y}}\right] ;\left[_{\mathrm{x}}\right.$ PRODUCE BY GENERATION $\left.\mathrm{y}_{\mathrm{y}}\right] ;\left[_{\mathrm{x}}\right.$ SURROUND/BE SURROUNDED $\left.{ }_{\mathrm{y}}\right]$, [ [ POSSESS/LACK $\mathrm{y}_{\mathrm{y}}$; [ [ RAMIFY $]$; [ [ BE PART OF/BE THE WHOLE $\mathrm{y}_{\mathrm{y}}$; [ [ BE ROUND]; [ [ BE ELONGATED];

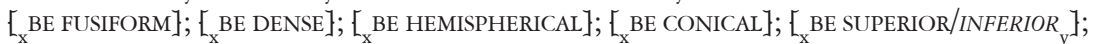

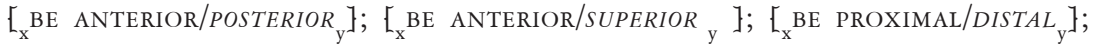
[ ${ }_{\mathrm{X}} \mathrm{BE}$ EXTREME/CENTRAL $]$

\section{- Semantic arguments}

- simple:

[encephalon], [sensory organs], [nervous centers], [brain], [muscle] [organ] [bone] [anatomical structure], [object], [thing], [body], [animal body], [pedunculus], [root], [geometrical base], [modified leaves], [green algae], [spore], [cell]

- complex (simplified):

[conidium], [sterigm], [basidium], [cephalo-bracchial chromosome], [inflorescence], [group of flowers], [involucre], [primary root], [anteridium], [gametangium]

\section{b) Activation of elements}

The questions that arise in this part of the analysis are: what elements (i.e. which predicates and which arguments) activate? how (order and relations) do they activate?, and why (factors of activation) do they activate?

Evidently, according to the activation, predicates are related in sense at different levels. To use a metaphor, each sense is a path, among many possible ones, in the "territory" of the LU's semantic information. For instance, the predicate ${ }_{x}$ BE PART OF ${ }_{y}$ appears as initial predicate in most of the senses of cabeza, but in c6 it activates recurrently, combined with other attributive predicates and with different semantic arguments.

$$
\begin{aligned}
& \left.\mathrm{c} 6={ }_{\mathrm{x}} \text { BE SUPERIOR PART [organism }\right]_{\mathrm{y}} ;\left[\text { cranium }_{j}\right]_{\mathrm{j}} \text { BE SUPERIOR POSTERIOR PART }{ }_{\mathrm{x}} ;\left[\text { face }_{\mathrm{k}}\right. \\
& \text { BE ANTERIOR PART } \\
& \mathrm{x}
\end{aligned}
$$

Activations (i.e. the senses activated in discourse) seem not to always start by the same predication: they would not be "paths" always beginning from the same "starting point". That is, in the LU predicates would not occupy a place nearer to or farther from a core (as in a radial structure), 
but rather we must note, for each sense, the predicate that gives way to activation. ${ }^{14}$

Thus, this implies that not all the activations of madre start, as we might believe, by ${ }_{\mathrm{x}}$ PRODUCE ${ }_{\mathrm{y}}$; by ${ }_{\mathrm{x}}$ BE PART OF ${ }_{\mathrm{y}}$, those of cabeza; or by ${ }_{\mathrm{x}}$ CONTAIN $_{\mathrm{y}}$, those of vaso. In any case, the fact that these predicates are those most shared by the senses of each LU does not mean that they all start by them, but rather that they are the most activated by said senses. This would demonstrate the core character of said predicate in the given LUs.

We are not denying the existence of the basic or generalizing notion of madre as origin, or of cabeza as part; we say that such notions are not themselves the semantic core of the LU, but that the predicates and arguments involved in said notions are shared by almost all of its senses. Each of the senses of these same predicates is not, or may not be, in the same position of the course.

Now then, the activation of semantic elements would be determined by different linguistic and context-situational factors. As linguistic factors we may note:

a) grammatical: lexical combinatory and syntax;

b) textual: textual type and genre.

The study of LUs in textual corpora would allow to prove the hypothetical character of observations and, moreover, to observe the activation factors.

\section{Specificity of specialized senses}

The third question arising from analysis referred to the specificity of specialized senses. According to the CTT, what renders a sense specialized are aspects of the communicational situation that activate certain features of the LU (Cabré, 1999); its cognitive conditions (Cabré; Feliu; Tebé, 2000), and its mode of signifying (Cabré \& Estopà, 2000).

\footnotetext{
14 This would lead to understand a representation of the sematic module of the LU as satelital, as proposed by Nuopponen (1997) for textual contents.
} 
The specificity of specialized senses is also related to (i) the semantic configuration of the activation and (ii) to the activated elements themselves.

- Semantic configuration:

a) embedding of predications: by "embedding of predications" we understand the phenomenon through which any predication may fill an argumental locus in another predicative relation. Specialized senses would present a high level of embedding. For instance, sense c13 of cabeza as part of the sporiferous reproductive apparatus of certain fungi. The information lexicographically expressed by basidium, sterigm and conidium is the following:

basidium $=\left[\left[_{\mathrm{b}} \text { BE PART OF [reproductive apparatus }\right]_{\mathrm{a}}\right]_{\mathrm{r}}$ BE PART OF [fungus $\left.]_{\mathrm{h}}\right]_{\mathrm{j}}$;

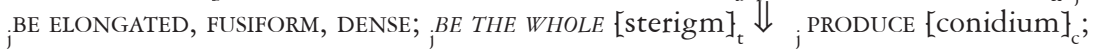

j BE PART OF [fungus $]_{h}$

conidium $=[\text { spore }]_{\mathrm{s}}$ PRODUCED by generation $\left.[\text { sterigm }]_{\mathrm{t}}\right]_{\mathrm{c}}$

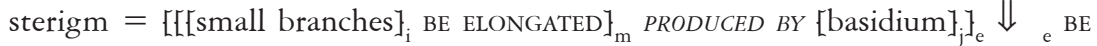
EXTREME PART OF [basidium $\left.]_{\text {j }}\right]_{t}$

Levels of embedding are multiple, and would allow for different levels of simplification of the representation:

$\mathrm{c} 13=\left[\text { conidium }_{c}{ }_{\mathrm{c}} \text { BE UNITED }[\text { sterigms }]_{\mathrm{t}}\right]_{\mathrm{x}}$ BE ROUND, BE TIGHT

(synthetic formula)

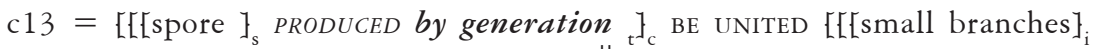
BE ELONGATED $]_{\mathrm{m}}$ PRODUCED BY [basidium $\left.]_{\mathrm{j}}\right]_{\mathrm{e}} \mathrm{O}$ e BE EXTREME PART [basidium $\left.]_{\mathrm{j}_{\mathrm{t}}}\right]_{\mathrm{x}}$ BE ROUND, BE TIGHT

(semi-synthetic formula)

$\mathrm{c} 13=\left[[\text { [spore }]_{\mathrm{s}} \text { PRODUCED by generation }{ }_{\mathrm{t}}\right]_{\mathrm{c}} \mathrm{BE}$ UNITED [[[ [small branches $]_{\mathrm{i}} \mathrm{BE}$ ELONGATED $]_{\mathrm{m}}$ PRODUCED BY $\left.\left[\mathrm{L}_{\mathrm{b}} \text { BE PART OF [reproductive apparatus }\right]_{\mathrm{a}}\right]_{\mathrm{r}}$ BE PART OF [fungus $\left.]_{h}\right]_{j} ;{ }_{j}$ BE ELONGATED, FUSIFORM, DENSE; ${ }_{j} B E$ THE $W H O L E E_{t} O{ }_{j}$ produce ${ }_{c} ;$ BE PART OF [fungus $\left.\left.]_{h}\right]_{j}\right]_{e} O$ BE EXTREME PART OF $\left.]_{\mathrm{t}}\right]_{\mathrm{x}}$ BE ROUND, BE TIGHT

(complete fórmula) 
b) relation between predications (in specialized senses, there seems that more relations of implication than of juxtaposition are activated, in opposition to what would occur in the corresponding non-specialized senses).

- Activation of semantic elements:

a) change of predicate (for instance, in the senses of "apophysis" of cabeza, the non-specialized sense (c16) changes the attributive predicate ${ }_{x}$ BE HEMISPHERICAL to ${ }_{x} B E$ ROUND);

b) change in the focalization of the faces of complex predicates;

c) change of semantic argument (i.e. change in denotation);

d) changes in the extension of the reference of semantic arguments;

e) changes in the intension of the semantic arguments.

Now then, these parameters do not seem to have the same incidence in the distinction (both theoretical and practical) of what is specialized. As an example, we observed the frequency of these parameters in the distinction between specialized and non-specialized variants of the analyzed units. Results would allow us to maintain that the three semantic parameters that characterize the specialized/non-specialized distinction are:

a) the situational factor, given the quantity of variants that do not show any change in semantic information;

b) the embedding of predications;

c) the change of semantic arguments.

In short, the kind of semantic information of the specialized sense does not differ from that of the non-specialized sense: they are distinguished only by their configuration. On the other hand, both types of senses share elements and, therefore, they maintain a polysemy relation: the main distinction seems to be the change of reference of semantic arguments.

\section{Conclusions}

We would like to briefly note that the observations undertaken allow us to demonstrate that polysemy is one of the explanatory factors of the nature of TUs. 
In fact, the LU model emerging from our analysis is also an explanation of lexical polysemy. In this sense, a polysemy model such as the one herein, presents the following explanatory advantages:

- it clarifies the nature of specialized senses, without recourse to an exclusive TU model;

- it accounts for other types of semantic variation and different subtypes of polysemy, described for the general language or for specialized uses;

- it constitutes a sustainable model even when specialized senses are not relevant, i.e. the proposal may be transcendent both for terminology and for general language studies.

andreina.adelstein@iula.upf.es teresa.cabre@trad.upf.es

\section{REFERENCES}

Adelstein, Andreína. 2001. Unidad léxica y valor especializado: estado de la cuestión y observaciones sobre su representación. Barcelona: Institut Universitari de Lingüística Aplicada. [Unpublished Master Thesis]

Adelstein, Andreína \& María Teresa Cabré. 2000. Representación lexicográfica y terminográfica de las unidades terminológicas. VII Simposio Iberoamericano de Terminología. Lisboa, 14 to 17 November 2000. Apresjan, Jurii Derenikovich. 1974. Regular polysemy. Linguistics. An International Review, 142. The Hague- Paris: Mouton: 5-32.

Bejornt, Henri \& Philippe Thoiron (dirs.). 2000a. In: Le sens en terminologie. Lyon: Presses Universitaires de Lyon.

. 2000b. Le sens des termes. In: Le sens en terminologie. Lyon: Presses Universitaires de Lyon: 5-17.

Bouveret, Myriam. 1998. Approche de la dénomination en langue spécialisée. Meta XLIII, 3: 393-410.

CABré, María Teresa. 1999. La terminología: representación y comunicación. Barcelona: Institut Universitari de Lingüística Aplicada de la Universitat Pompeu Fabra.

. 2000a. Sur la représentation mentale des concepts: bases pour une tentative de modélisation. In: Bejornt, Henri \& Philippe Thorron (dirs.) 2000. Le sens en terminologie. Lyon: Presses Universitaires de Lyon: 21-37. 
. 2000b. Terminologie et linguistique: la théorie des portes. In: Terminologies nouvelles, 21: 10-15.

Cabré, Maria Teresa \& Andreína Adelstein. 2001. ¿Es la terminología lingüística aplicada?. In: Muñoz, Carmen (coord.) Trabajos en Lingüística Aplicada. Barcelona: Univerbook, S.L.:387-393.

Cabré, Maria Teresa \& Rosa Estopà. 2000. El conocimiento especializado y sus unidades de representación: diversidad cognitiva. [In: II Congreso de la Asociación Española de Lingüística Cognitiva (AELCO), Madrid, 17 to 20 May 2000]

Condamines, Anne. 1994. Terminologie et représentation des connaisances. In: La banque des mots Número Spécial 1994: 29-44.

. 1995. Terminology: New needs, new perspectives. In: Terminology, 2(2): 219-238.

Condamines, Anne \& Josette Rebeyrolle. 1997. Point de vue en langue spécialisée. In: Meta, XLII (1): 174-184.

Coseriu, Eugenio. 1977. Principios de semántica estructural. Madrid: Gredos.

Cruse, David. 1986. Lexical Semantics. Cambridge: Cambridge University Press.

Desmet, Isabel \& Samy Boutayeb. 1994. Terms and words: propositions for terminology. In: Terminology, 1(2): 303-325.

Felber, Helmut.1984. Terminology Manual. París: Unesco - Infoterm United Nations Educational, Scientific and Cultural Organization.

Fillmore, Charles \& B. T. S. Atkins. 2000. Describing Polysemy: The Case of 'Crawl'. In: Ravin, Yael \& Claudia Leacock (eds.). 2000. Polysemy. Theoretical and computational approaches. Oxford: Oxford University Press: 91-110.

Geeraerts, Dirk. 1990. The lexicographical treatment of prototypical polysemy. In: Tsohatsidis, Savas (ed.) Meanings and prototypes: studies in linguistic categorisation. London: Routledge:195-210.

.1995. Representational formats in cognitive semantics. In: Folia Lingüística, XXIX (1-2): 21-41.

Geeraerts, Dirk; Grondelaers, Stefan \& Peter Bakema. 1994. The Structure of lexical variation meaning, naming, and context. Berlin: Mouton de Gruyter.

Guilbert, Louis. 1975. La créativité lexicale. Paris: Larousse.

Kleiber, Georges. 1999. Problèmes de sémantique. La polysémie en questions. París: Presses Universitaires du Septentrion.

LAKOFF, George. 1987. Women, fire and other dangerous things: what categories reveal about the mind. Chicago: University of Chicago Press, 1990. 
LARA, Luis Fernando. 1998/1999. 'Concepts' and Term Hierarchy. In: Terminology, 5 (1): 59-76.

1999. Término y cultura: hacia una teoría del término. In: CABRÉ, M. T. (dir.) Terminología y modelos culturales. Barcelona: Institut Universitari de Lingüística Aplicada, Universitat Pompeu Fabra: 39-60.

LeECH, Geoffrey. 1981. Semántica. Madrid: Alianza, 1985.

Lyons, John. 1981. Lenguaje, significado y contexto. Barcelona / Buenos Aires: Editorial Paidós.

Meyer, Ingrid \& Kristen Mackintosh. 2000. 'L'étirement' du sens terminologique: aperçú du phénomène de la déterminologisation"représentation mentale des concepts: bases pour une tentative de modélisation. In: Bejoint, Henri \& Philippe Thoiron (dirs.). 2000. Le sens en terminologie. Lyon: Presses Universitaires de Lyon: 198-217.

Meyer, Ingrid; Mackintosh, Kristen \& Krista Varantola. 1997. Exploring the reality of virtual: on the lexical implications of becoming a knowledge society. In: Lexicology, 3 (1):129-163.

Mounin, Georges. 1972. La sémantique. Paris: Éditions Payot \& Rivages, 1997.

Moura, Herónies. 2001. Dénotation et argumentation dans le discours. In: Langages (142): 77-91.

Nuopponen, Anita. 1997. A model for systematic terminological analysis. In: Proceedings of the $11^{\text {th }}$ Symposium of LSP, Copenhagen Business School, 18-22 august 1997. [On print]

Picht, Heribert. 1996. En record de Wüster: la multidisciplinarietat de la terminologia. In: CABRÉ, Maria Teresa (dir). Terminologia. Selecció de textos d'E. Wüster. Barcelona: Servei de llengua Catalana: 253-287.

Pustejovsky, James. 1995. The Generative Lexicon. Cambridge: MIT Press.

Rastier, François. 1987. Sémantique interprétative. Paris: PUF.

Ravin, Yael \& Claudia Leacock. 2000. Polysemy: an Overview. In: Ravin, Yael \& Claudia LeAcock (eds.) Polysemy. Theoretical and computational approaches. Oxford: Oxford University Press: 1-29.

Récanati, François. 1997. La polysémie contre le fixisme. In: Langue Française (113): 107-123.

Rey, Alain. 1998/1999. Terminology between the experience of reality and the command of signs. In: Terminology, 5 (1): 121-134.

RoNDEAU, Guy. 1984. Introduction à la terminologie. (2e éd). Quebec: Gaëtan Morin Éditeur. 2e edición. [1 ${ }^{\circ}$ ed. es de 1981]

SAGER, Juan Carlos. 1998/1999. In search of a foundation: Towards a theory of the term. In: Terminology, 5 (1): 41-57. 
. 2000. Pour une approche fonctionnelle de la terminologie. In: BejoInt, Henri \& Philippe Thoiron (dirs.) (2000). Le sens en terminologie. Lyon: Presses Universitaires de Lyon: 40-60.

SlodzIAN, Monique. 1995. Comment revisiter la doctrine terminologique aujourd'hui?. In: La Banque des Mots, Numéro spécial 7/1995: 11-18. 2000. L'emergence d'une terminologie textuelle et le retour du sens. In: Bejornt, Henri \& Philippe Thoiron (dirs.) (2000). Le sens en terminologie. Lyon: Presses Universitaires de Lyon: 61-85.

Temmerman, Rita. 1995. The process of revitalisation of old words: splicing. A case study in the extension of reference. In: Terminology, 2 (1):107128.

Temmerman, Rita. 1997. Questioning the univocity ideal. The difference between socio-cognitive Terminology and traditional Terminology. In: Hermes; Journal of Linguistics (18): 51-90.

Temmerman, Rita. 1998. Towards new ways of terminology description: the sociocognitive approach Amsterdam: John Benjamins, 2000.

. 1998/1999. Why traditional Terminology Theory impedes a realistic description of categories and terms in the life science. In: Terminology, 5 (1): 77-92.

ViCTORRI, Bernard. 1996. La construction dynamique du sens. In: PorTE, M. (dir) Passion des formes. Sant-Cloud: Éditions de l'ENS de FontenaySaint-Cloud: 733-747.

Victorri, Bernard \& Catherine Fuchs. 1996. La polysemie: construction dynamique du sens. Paris: Hermès Science Publication.

Wüster, Eugen. 1974. La teoria general de la terminologia: una zona fronterera entre la lingüística, la lògica, l'ontologia, la informàtica i les ciències especialitzades. In: CABRÉ, Maria Teresa (dir) Terminologia. Selecció de textos d'E. Wïster. Barcelona: Servei de Llengua Catalana, Universitat de Barcelona, 1996:153-202. 


\section{ANNEX I. DICTIONARIES}

\section{Spanish language dictionaries}

[DRAE] Diccionario de la lengua española de la Real Academia Española. Madrid: Espasa Calpe, 1992.

[VOX] Diccionario general ilustrado de la lengua española. Barcelona: Bibliograf, 1993.

[GDLE] Gran diccionario Larousse de la lengua española. Barcelona: Larousse Planeta, 1996.

[DEA] Seco, Manuel; Andrés, Olimpia; Ramos, Gabino (1999) Diccionario del español actual. Madrid: Aguilar.

\section{Science dictionaries}

[DRAC] Academia de Ciencias Exactas, Físicas y Naturales (1996) Vocabulario científico y técnico. Madrid: Espasa-Calpe.

[DTCT] Diccionario de términos científicos y técnicos. México: McGraw-Hill Boixeareu, 1981.

[DCHC] Collocott, C. (dir.) (1940) Diccionario científico y tecnológico: españolinglés-francés-alemán. Tomo 1. Barcelona: Omega, 1979.

\section{Botany dictionaries}

[BOTV] Gran vox diccionario de botánica y zoología. Barcelona: Biblograf, 1995.

[BOTA] Font Quer, P. (dir.) (1953) Diccionario de botánica. Barcelona: Labor, 2000.

[BOTB] Diccionarios Rioduero. Botánica. Madrid: Rioduero, 1979.

\section{Chemistry dictionaries}

[QUIMV] Gran vox diccionario de química. Barcelona: Biblograf, 1995.

[QUIMH] Hawley, Gessner Goodrich (1987) Diccionario de química y de productos químicos. Barcelona: Omega, 1993.

[QUIMS] Miall, Stephen (1943) Diccionario de química. México, D.F.: Atlante. 


\section{Medicine dictionaries}

[MEDV] Gran vox diccionario de medicina. Barcelona: Biblograf, 1994.

[MEDD] Dorland, William Alexander Newman (1997) Diccionario enciclopédico ilustrado de medicina Dorland. Madrid: McGraw-Hill Interamericana de España.

[MEDA] Anguiano Rueda, Cristino (1988) Diccionario de ciencias médicas. Buenos Aires: El Ateneo.

[MEDT] Diccionario terminológico de ciencias médicas. Barcelona: Ediciones Científicas y Técnicas, 1991.

\section{Biology dictionaries}

[BIOV] Gran vox diccionario de biología. Barcelona: Biblograf, 1993.

[BIOR] Chauvin, Rémy (dir.) (1982-1988) La Biología. Bilbao: Mensajero.

[BIOH] Holmes, Sandra (1985) Henderson diccionario de términos biológicos. Madrid: Alhambra.

[BIOM] Parker, Sybil P. (ed.) (1991) Diccionario McGraw-Hill de biología: bilingüe español-inglés, English-Spanish. México D.F.: McGraw-Hill. 


\section{ANNEX II. DELIMITATION AND GROUPIND OF SENSES OF CABEZA}

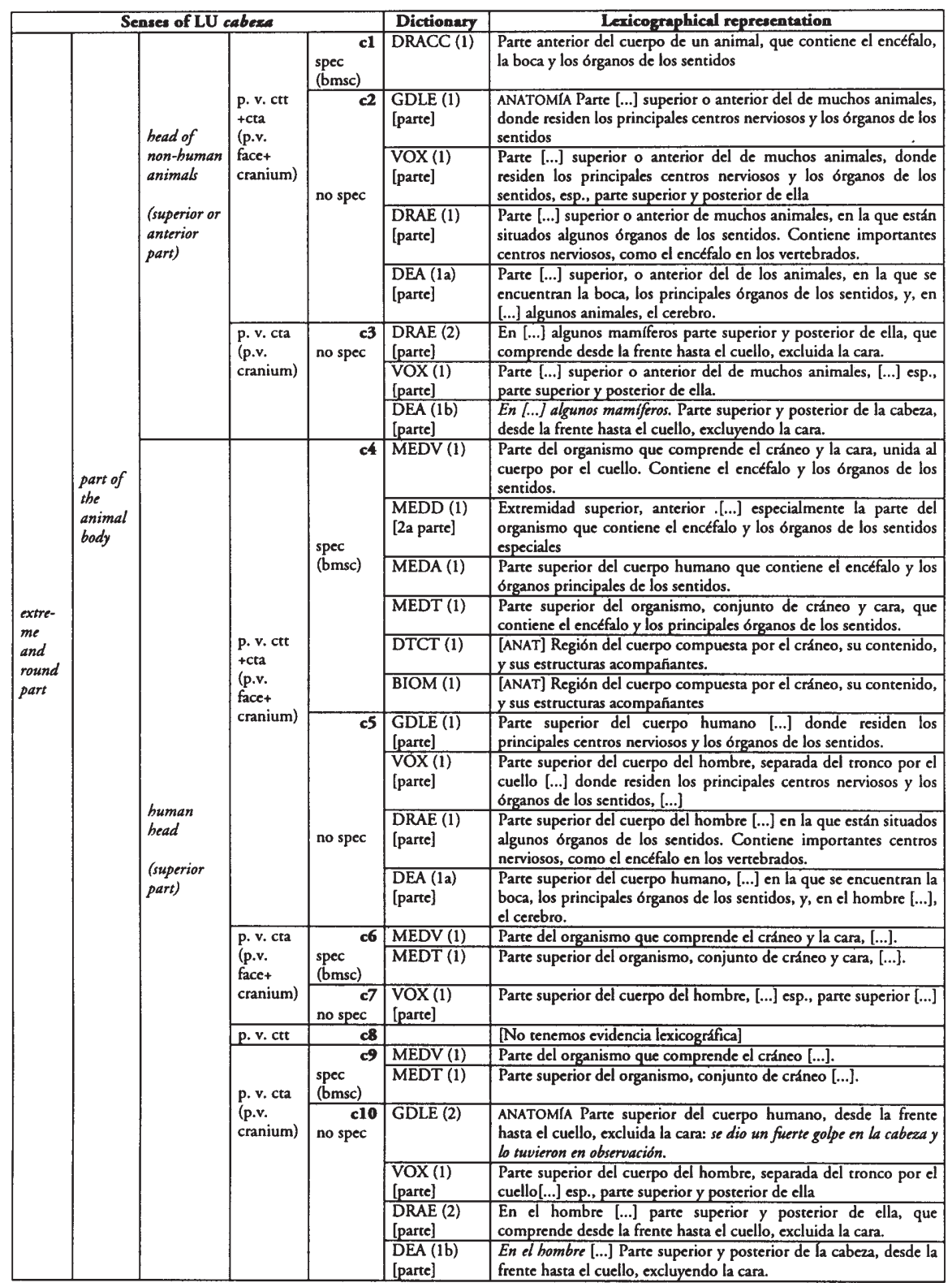

Table 1. Delimitation and grouping of senses of cabeza: c1 a c10 


\begin{tabular}{|c|c|c|c|c|c|c|}
\hline \multicolumn{5}{|c|}{ Senses of LU cabera } & \multirow{2}{*}{$\begin{array}{l}\text { Dictionary } \\
\text { MEDA (2) }\end{array}$} & Lexicographical representation \\
\hline \multirow{9}{*}{$\begin{array}{l}\text { extreme } \\
\text { and } \\
\text { round } \\
\text { part }\end{array}$} & \multirow{9}{*}{$\begin{array}{l}\text { of some- } \\
\text { thing }\end{array}$} & \multirow{3}{*}{$\begin{array}{l}\text { non- } \\
\text { specific } \\
\text { reference }\end{array}$} & \multirow{2}{*}{\multicolumn{2}{|c|}{ spec (bmsc) }} & & $\begin{array}{l}\text { Extremidad de una parte o estructura anatómica de forma } \\
\text { ensanchada o redondeada. }\end{array}$ \\
\hline & & & & & MEDT (2) & Organo o parte en forma de cabeza. \\
\hline & & & \multicolumn{2}{|l|}{ no spec } & GDLE (4) & $\begin{array}{l}\text { Extremo abultado, ensanchado o redondeado de cualquier } \\
\text { objeto, opuesto a la punta: solo se veian las cabezas de los alfileres } \\
\text { clavados en el acerico. }\end{array}$ \\
\hline & & \multirow{6}{*}{$\begin{array}{l}\text { specific } \\
\text { reference }\end{array}$} & \multicolumn{2}{|c|}{$\begin{array}{l}\text { c13 } \\
\text { repr organ of fungus } \\
\text { spec (bot) }\end{array}$} & $\mathrm{DCHC}(1)$ & $\begin{array}{l}\text { Grupo de esterigmas y conidios, apretados en densa masa, de } \\
\text { perfil redondeado. }\end{array}$ \\
\hline & & & \multicolumn{2}{|c|}{$\begin{array}{l}\text { cell of algae } \\
\text { reproductor apparatus } \\
\text { spec (bot) }\end{array}$} & BOTA (4) & $\begin{array}{l}\text { En el anteridióforo de los carófitos se llaman cabezas primarias, } \\
\text { o sencillamente cabezas, las células que se implantan } \\
\text { aisladamente en el extremo de cada manubrio, y que sostienen } \\
\text { un número variable (3-8) de cabezas secundarias o cabecilas, a } \\
\text { las que dan origen. - R. M. }\end{array}$ \\
\hline & & & \multicolumn{2}{|c|}{$\begin{array}{r}\mathrm{c15} \\
\text { chromosome spec (bot) } \\
\end{array}$} & BOTA (3) & Extremo muy pequefio de un cromosoma cefalobraquial. \\
\hline & & & \multirow{2}{*}{$\begin{array}{l}\text { Apo- } \\
\text { physis } \\
\text { no spec }\end{array}$} & $\begin{array}{l}\text { c16 } \\
\text { semi spec } \\
\text { (bmsc) }\end{array}$ & $\begin{array}{l}\text { DEA (2c) } \\
\text { [sin def] }\end{array}$ & $\begin{array}{l}\text { [...] Navarro Biología 81: Cuando las apófisis son hemisféricas } \\
\text { se denominan cabezas. }\end{array}$ \\
\hline & & & & $\begin{array}{r}\mathbf{c 1 7} \\
\text { no spec }\end{array}$ & $\begin{array}{l}\mathrm{DEA}(2 \mathrm{c}) \\
{[\sin \mathrm{ej}]}\end{array}$ & (Anat) Apófisis redondeada [de un hueso] [...]. \\
\hline & & & \multicolumn{2}{|c|}{$\begin{array}{l}\text { elongated } \\
\text { no spec }\end{array}$} & DEA (2b) & $\begin{array}{l}\text { Extremo abultado o ensanchado de un objeto de forma } \\
\text { alargada. Mature Memoria } 115:[\ldots] \text { con ciudades como } \\
\text { cabezas de alfileres }[\ldots]\end{array}$ \\
\hline
\end{tabular}

Table 2. Delimitation and grouping of the senses of cabeza: c11 a c18

\begin{tabular}{|c|c|c|c|c|c|}
\hline \multicolumn{4}{|c|}{ Senses of LU cabeza } & Dictionary & Lericographical representation \\
\hline \multirow{14}{*}{$\begin{array}{l}\text { Extre } \\
\text { me } \\
\text { part }\end{array}$} & \multirow{4}{*}{$\begin{array}{l}\text { non-specific } \\
\text { location }\end{array}$} & \multirow{3}{*}{$\begin{array}{l}\text { non-specific } \\
\text { reference }\end{array}$} & $\begin{aligned} c 19 \\
\text { spec (bmsc) }\end{aligned}$ & MEDA (2) [par] & Extremidad de una parte [...]. \\
\hline & & & \multirow{2}{*}{ no spec } & VOX $(5)\left[1^{\circ} \mathrm{par}\right]$ & Principio o parte extrema de una cosa, [...]. \\
\hline & & & & GDLE (3) & Principio o parte extrema de una cosa. \\
\hline & & $\begin{array}{l}\text { of something } \\
\text { elongated }\end{array}$ & no spec ${ }^{c 21}$ & DEA (2a) & Extremo de un objeto de forma alargada. \\
\hline & \multirow{3}{*}{ p.v. } & \multirow[b]{2}{*}{$\begin{array}{l}\text { non-specific } \\
\text { reference }\end{array}$} & \multirow{2}{*}{ no spec } & DEA (5a) & Parte superior de una cosa. \\
\hline & & & & $\begin{array}{l}\text { VOX }(5)\left[2^{\circ}\right. \\
\text { parte] }\end{array}$ & Principio o parte extrema de una cosa, esp. la superior [...]. \\
\hline & & \multirow{3}{*}{ structure, body } & $\mathbf{c 2 3}$ & MEDT (3) & Parte superior [...] de una estructura (músculo, etc.) \\
\hline & \multirow[b]{2}{*}{ superior } & & spec (bmsc) & MEDD (1) [parte] & Extremidad superior, $[\ldots]$ de una estructura o cuerpo, $[\ldots]$ \\
\hline & & & no spec c24 & DEA (5c) [par] & (Anat) Parte superior [...] de un músculo o de un órgano. \\
\hline & \multirow{3}{*}{$\begin{array}{l}\text { p.v. } \\
\text { proximal }\end{array}$} & \multirow{3}{*}{ structure, body } & c25 & MEDT (3) [parte] & Parte [...] proximal de una estructura (músculo, etc. ) \\
\hline & & & spec (bmsc) & MEDD (1) [parte] & Extremidad $[. .$.$] proximal de una estructura o cuerpo, [\ldots]$ \\
\hline & & & no spec & $\begin{array}{l}\text { DEA (5c) } \\
\text { [parte] }\end{array}$ & (Anat) Parte [...] proximal de un músculo o de un órgano. \\
\hline & \multirow{2}{*}{$\begin{array}{l}\text { p.v. } \\
\text { anterior }\end{array}$} & $\begin{array}{l}\text { non-specific } \\
\text { reference. }\end{array}$ & no spec $^{c 27}$ & DEA (6a) & Parte anterior de una cosa. \\
\hline & & structure, body & esp (bmsc) & MEDD (1) [parte] & Extremidad $[\ldots]$ anterior $[\ldots]$ de una estructura o cuerpo, $[\ldots]$ \\
\hline
\end{tabular}

Table 3. Delimitation and grouping of the senses of cabeza: c19 a c28 


\begin{tabular}{|c|c|c|c|c|c|c|}
\hline \multicolumn{5}{|c|}{ Senses of LU cabera } & \multicolumn{2}{|r|}{ Lexicographical representation } \\
\hline \multirow{14}{*}{$\begin{array}{l}\text { round } \\
\text { part }\end{array}$} & non-specific & efference & & $\begin{array}{l}\text { c29 } \\
\text { spec } \\
\text { (bmsc) }\end{array}$ & $\begin{array}{l}\text { MEDA (2) } \\
{\left[2^{\circ} \text { parte] }\right.}\end{array}$ & $\begin{array}{l}\text { [...] estructura anatómica de forma ensanchada o } \\
\text { redondeada. }\end{array}$ \\
\hline & \multirow{13}{*}{$\begin{array}{l}\text { specific } \\
\text { reference }\end{array}$} & \multirow{11}{*}{ inflorescence } & \multirow{2}{*}{\multicolumn{2}{|c|}{ spec (bot) }} & $\mathrm{DCHC}(2)$ & $\begin{array}{l}\text { Densa inflorescencia de pequerias y apretadas flores, } \\
\text { usualmente sésiles, rodeadas de un involucro. }\end{array}$ \\
\hline & & & & & $\begin{array}{l}\text { BOTA (2) } \\
\text { (cabezuel 1) }\end{array}$ & $\begin{array}{l}\text { Cabezuela = cabezuela Término con que los } \\
\text { romancistas españoles ([...]) tradujeron el vocablo } \\
\text { capitulum, con que LiNNE designó las "flores } \\
\text { compuestas", y que todavia hoy se emplea como sin. } \\
\text { de capitulo. }\end{array}$ \\
\hline & & & \multirow{9}{*}{$\begin{array}{l}\text { no spec } \\
\text { (bot) }\end{array}$} & \multirow[t]{2}{*}{$\begin{array}{l}\text { semi } \\
\text { spec. }\end{array}$} & $\begin{array}{l}\text { DEA (cabezuel } \\
\text { 1) [ejemplo] }\end{array}$ & $\begin{array}{l}\text { cabezuela [...] } \mid \text { Ybarra-Cabetas Ciencias 274: Son } \\
\text { inflorescencias indefinidas de flores sentadas, el } \\
\text { amento, constiruido por un eje en que se asientan las } \\
\text { flores que son unisexuales; la espiga, en que las flores } \\
\text { son hermafroditas; cabezuela, si las flores están } \\
\text { insertas en la terminación del pedúnculo, etc. }\end{array}$ \\
\hline & & & & & $\begin{array}{l}\text { DEA (capítulo } \\
\text { 6) [ejemplo] }\end{array}$ & $\begin{array}{l}\text { [...] Bustinza-Mascaró Ciencias 259: Hay muchos } \\
\text { tipos [de inflorescencias], entre ellos, como más } \\
\text { frecuentes: racimo ..; cabezuela o capítulo, reunión de } \\
\text { flores sin pedúnculo colocadas paralelamente y } \\
\text { apretadas sobre un involucro o ensanchamiento del } \\
\text { pedúnculo de la inflorescencia. }\end{array}$ \\
\hline & & & & \multirow{4}{*}{ no spec } & $\begin{array}{l}\text { DRAE } \\
\text { (capitulo 9) }\end{array}$ & capitulo Bot. cabezuela, inflorescencia. \\
\hline & & & & & $\begin{array}{l}\text { DRAE } \\
\text { (cabezuel 6) }\end{array}$ & $\begin{array}{l}\text { cabezuela Bot. Inflorescencia cuyas flores, que son } \\
\text { sentadas o tienen un pedúnculo muy corto, están } \\
\text { insertas en un receptáculo, comúnmente rodeado de } \\
\text { brácteas. }\end{array}$ \\
\hline & & & & & $\begin{array}{l}\text { DEA (capitulo } \\
\text { 6) }[\sin \mathrm{ej}]\end{array}$ & capitulo (Bot) Cabezuela (inflorescencia). \\
\hline & & & & & $\begin{array}{l}\text { GDLE } \\
\text { (cabezuel 1) }\end{array}$ & $\begin{array}{l}\text { BOTÁNICA Inflorescencia sentada sobre un } \\
\text { receptáculo común, rodeada de brícteas, propia de las } \\
\text { plantas compuestas. }\end{array}$ \\
\hline & & & & \multirow{3}{*}{ - spec } & $\begin{array}{l}\text { DEA (cabezuela } \\
\text { 1) [sin ej] } \\
\end{array}$ & $\begin{array}{l}\text { cabezuela Inflorescencia cuyas flores, sin pedúnculo, } \\
\text { surgen de un eje deprimido y ensanchado [...] }\end{array}$ \\
\hline & & & & & $\operatorname{VOX}(3)$ & $\begin{array}{l}\text { Cabezuela = Inflorescencia de flores sentadas sobre } \\
\text { un receptáculo común, rodeada por un involucro de } \\
\text { brácteas; es propia de la familia de las compuestas }\end{array}$ \\
\hline & & & & & VOX (5) & $\begin{array}{l}\text { capítulo - Inflorescencia densa de flores sésiles } \\
\text { dispuestas sobre un pedúnculo aplanado. }\end{array}$ \\
\hline & & $\begin{array}{l}\text { receptacle of } \\
\text { inflorescence }\end{array}$ & \multicolumn{2}{|c|}{ spec. (bot) } & $\begin{array}{l}\text { BOTA (2) } \\
\text { (cabezuela 2) }\end{array}$ & $\begin{array}{l}\text { Cabezuela = cabezuela Para Gándara, Sist., p.174, } \\
\text { receptáculo del capírulo. }\end{array}$ \\
\hline & & root & \multicolumn{2}{|c|}{ spec (bot) c35 } & BOTA (1) & $\begin{array}{l}\text { Término usual con que se designa la base de la raf́ } \\
\text { maestra o primaria. }\end{array}$ \\
\hline
\end{tabular}

Table 4. Delimitation and grouping of the senses of cabeza: c29 a c35

These tables represent the integral senses delimitation of cabeza. Italics indicate a minimum definition, in order to identify a sense or group of senses. Numbers after dictionary codes indicate the definition number. The kinds of senses are distinguished according to: specialized character, thematic field or domain, and point of view. Abbreviations used are the following:

spec $=$ specialized

semi spec $=$ lower degree of specialization

no spec $=$ not specialized 
(bot) $=$ botany

$(\mathrm{bmsc})=$ biological and medical sciences

p.v. $c t t+c t a=$ content and container point of view

p.v. cta $=$ container point of view

p.v. ctt $=$ content point of view

p.v. face + cranium $=$ face and cranial point of view

p.v. cranium $=$ cranial point of view 